\title{
The Anthelmintic Activity of Cawat Anuman (Bauhinia Sp.) Leaves Against Ascaridia galli Worms
}

\author{
Ruqiah Ganda Putri Panjaitan*, Ela Elisa, Eko Sri Wahyuni
}

\section{Ruqiah Ganda Putri Panjaitan*, Ela Elisa, Eko Sri Wahyuni}

Department of Biology Education, Faculty of Teacher Training and Education, Tanjungpura University. Jl. Prof. Dr. $\mathrm{H}$. Hadari Nawawi, Bansir Laut, Kec. Pontianak Tenggara, Kota Pontianak, West Kalimantan 78124, INDONESIA

\section{Correspondence}

\section{Ruqiah Ganda Putri Panjaitan}

Department of Biology Education, Faculty of Teacher Training and Education

Tanjungpura University JI. Prof. Dr.

H. Hadari Nawawi, Bansir Laut, Kec.

Pontianak Tenggara, Kota Pontianak, West Kalimantan 78124, INDONESIA.

E-mail: ruqiah.gpp@fkip.untan.ac.id

History

- Submission Date: 14-12-2020;

- Review completed: 19-01-2021;

- Accepted Date: 23-02-2021

DOI : $10.5530 / p j .2021 .13 .79$

Article Available online http://www.phcogj.com/v13/i3

\section{Copyright}

(C) 2021 Phcogi.Com. This is an openaccess article distributed under the term of the Creative Commons Attribution 4.0 International license.

\section{ABSTRACT}

Background: Traditionally, the people in Anik Hamlet usually use the Bauhinia sp. leaves as anthelimintic. Objective: The research was conducted to observe the anthelmintic activity of the ethanol extract of cawat anuman (Bauhinia sp.) leaves against Ascaridia galli by in vitro procedure. Methods: Group I was treated with $\mathrm{NaCl} 0.9 \%$ as the negative control, also group II and III were treated with cawat anuman leaves ethanol extract at dose of $25 \mathrm{mg} / \mathrm{ml}$ and $50 \mathrm{mg} /$ $\mathrm{ml}$ respectively, and group IV was treated with mebendazole at dose $5 \mathrm{mg} / \mathrm{ml}$ as the positive control. Results: Compared to the negative control, the ethanol extract of cawat anuman leaves has activity as an anthelmintic $(p<0.05)$, moreover the potency of leaves extract at dose $50 \mathrm{mg} / \mathrm{ml}$ as anthelmintic against Ascaridia galli as strong as mebendazole at dose $5 \mathrm{mg} / \mathrm{ml}$ ( $p>0.05$ ). Conclusion: It concluded that the ethanol extract of cawat anuman leaves at dose $50 \mathrm{mg} / \mathrm{ml}$ has anthelmintic potency as strong as mebendazole $5 \mathrm{mg} / \mathrm{ml}$.

Key words: Anthelmintic activity, Ascaridia galli, Bauhinia sp. Leaves.

\section{INTRODUCTION}

Worm infection or worm disease is a disease that occurs without clear clinical symptoms, that's why this disease has received less attention. However, this disease cannot be underestimated because it causes, among others, malnutrition, as well as disruption in children's development and cognitive development. That is why various efforts are being made to reduce the incidence of worm infections in children. ${ }^{1,2}$

Worms can become parasites and cause worms disease. Several types of worms can infect humans, including Ascaris lumbricoides, Fasciola hepatica, Enterobius vermicularis, Ancylostoma duodenale, and Taenia solium. ${ }^{1}$ These worms are usually known as stomach worms because they are generally in the small intestine which contains lots of food, but stomach worms also exist in the large intestine. Generally, humans are infected with worms through food or drink contaminated with worm eggs and enter the human digestive tract $^{3}$. World Health Organization data in 2012 showed that two billion people in the world have been infected with worms. ${ }^{4}$ Previously, the data from the Ministry of Health of the Republic of Indonesia in 2009 showed the prevalence of worm infections in Indonesia was $24.1 \%{ }^{5}$ The causes of high worm infections in Indonesia are related to Indonesia's geographic location in the tropics, as well as the lack of sanitation and public awareness in maintaining personal hygiene, as well as the low level of public education. ${ }^{2}$

Anik Hamlet is one of the hamlets located in West Kalimantan, Indonesia. The results of observations and interviews with the local community show that community awareness is still low in maintaining personal hygiene. This is indicated by the lack of public awareness to wash their hands before eating. Besides, the lack of public awareness of maintaining environmental sanitation is indicated by the fact that many houses do not have latrines and the habit of people preferring to defecate in the river. In connection with this situation, from the results of interviews with midwives and the local community, it was found that almost all children between the ages of 3-6 years had worms. Usually, people in Anik Hamlet use deworming drugs on the market, but many people use traditional medicines derived from plants.

Anthelmintic or worm medicine is a drug that can destroy and eradicate parasitic worms in the human and animal bodies by eradicating or killing them. Anthelmintic does not only work by eradicating worms in the digestive tract but also by eradicating worm larvae that infest the organs and tissues of the body. ${ }^{6}$ Deworming drugs that are now widely used, but there are concerns that these drugs have side effects, so it is necessary to find other alternatives to treat worms at low prices but have powerful properties and do not give side effects to users, one of which is using traditional or natural plants. ${ }^{8}$

Until now, in rural areas, there are still many traditional or natural remedies used to treat intestinal worms which is hereditary knowledge. Several types of plants that have been known to be used as anthelmintics are tobacco, walnuts, cloves, garlic, pineapples, soybeans, and peas, as well as honey, water, and vinegar mixed with warm water. ${ }^{9}$ The results of the literature study show that the anthelmintic test of the cawat anuman has never been done. Even so, the residents of Anik Hamlet have known the properties of the cawat anuman plant as an anti-worm medicine and have used it from generation to generation. Based on the above explanation, this study aims to evaluate the anthelmintic activity of cawat anuman leaves.

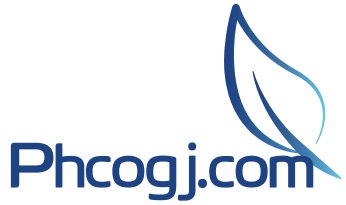

Cite this article: Panjaitan RGP, Elisa E, Wahyuni ES. The Anthelmintic Activity of Cawat Anuman (Bauhinia Sp.) Leaves Against Ascaridia galli Worms. Pharmacog J. 2021;13(3): 62630. 


\section{MATERIALS AND METHODS}

\section{Sample preparation and sample extraction}

The cawat anuman plant is taken from Anik Hamlet, Menyuke District, Landak Regency, West Kalimantan-Indonesia. Type identification was carried out at the Biological Research Center, Cibinong, West JavaIndonesia, the identification results were reported in letter number 2035/IPH.1.01/If.07/VIII /2018. Extraction procedure refers to Harborne. ${ }^{10}$ A total of 821 grams of cawat anuman leaves were washed then dried. The dried leaves are then powdered, macerated with ethanol at concentration $96 \%$ which is distilled for $3 \times 24$ hours at room temperature. Furthermore, the filtrate was evaporated at a temperature of $\pm 40^{\circ} \mathrm{C}$ to obtain a concentrated extract of 8.96 grams.

\section{Preparation of test animals}

The worms used are worms that are in the intestines of chickens. The worms are obtained from chicken slaughterhouses in Pontianak City. After being taken from the intestinal lumen, the worms are rinsed with $\mathrm{NaCl} 0.9 \%$. The type of worms was then identified, and the results of the identification carried out by the Pontianak City Veterinary Center were reported on letter number 17181 .

\section{Qualitative phytochemical test}

The groups of secondary metabolites identified are alkaloids, flavonoids, tannins, phenols, steroids, terpenoids, saponins, and glycosides. The procedure for identifying groups of secondary metabolites was carried out according to Harborne. ${ }^{10}$

\section{Anthelmintic activity test}

According to Tiwow et al. (2013) $)^{11}$ the anthelmintic activity test conducted was in vitro test. There were 20 Ascaridia galli in groups of four and each group consisted of five. The first group or negative control was given $\mathrm{NaCl} 0.9 \%$, the second and third groups were given ethanol extract of cawat anuman leaves at a dose of $25 \mathrm{mg} / \mathrm{ml}$ and $50 \mathrm{mg} / \mathrm{ml}$, and the fourth group or positive control with mebendazole at dose 5 $\mathrm{mg} / \mathrm{ml}$. The dosage of mebendazole refers to Tjay \& Rahardja (2007). ${ }^{6}$ Furthermore, the worms were immersed in the test preparation, soaking was carried out separately for each individual. Immersing was carried out for 24 hours, and during that time observations were made to determine the time for paralysis and death of worms.

\section{Data analysis}

Overall, the data obtained for paralysis time and time of death were analyzed statistically using the SPSS version 17 and continued with the Tukey test at the $5 \%$ level if significantly different.

\section{RESULTS AND DISCUSSION}

The use of anuman cawat leaf as an anthelmintic by the Anik hamlet has been carried out from generation to generation. Usually, people use old leaves and young leaves, the processing method is by boiling 5-10 leaves with $500 \mathrm{ml}$ to $1 \mathrm{~L}$ of water. Boiling is carried out until the water boils, the boiled water is then cooled, then the boiled water is drunk twice a day for one to three days or until the worm's condition has improved. As stated by Manalu \& Biran (2006) $)^{15}$ someone who suffers from worms will experience malnutrition and decreased endurance, besides that in children it will cause growth and development disorders. The results of the anthelmintic power test of the ethanol extract of cawat anuman leaves are as follows (Tables 1 and 2).

According to Tjay \& Rahardja $(2007)^{6}$ anthelmintic is a substance that works locally to eradicate worms and worm larvae in the digestive tract. The ideal anthelmintic is one that is effective and safe. Moreover, people usually prefer oral anthelmintics with a single dose.

\begin{tabular}{|c|c|c|c|c|}
\hline No. & Group & Number of Worms & $\begin{array}{l}\text { Time of Paralysis } \\
\text { (hours) }\end{array}$ & $\begin{array}{l}\text { Time of Death } \\
\text { (hours) }\end{array}$ \\
\hline \multirow[t]{5}{*}{1.} & Mebendazole at dose $5 \mathrm{mg} / \mathrm{ml}$ & 1 & 12 & 13 \\
\hline & & 1 & 13 & 14 \\
\hline & & 1 & 12 & 16 \\
\hline & & 1 & 12 & 17 \\
\hline & & 1 & 13 & 18 \\
\hline \multirow[t]{5}{*}{2.} & Cawat anuman leaves ethanol extract at dose $25 \mathrm{mg} / \mathrm{ml}$ & 1 & 13 & 16 \\
\hline & & 1 & 14 & 17 \\
\hline & & 1 & 13 & 18 \\
\hline & & 1 & 14 & 19 \\
\hline & & 1 & 13 & 20 \\
\hline \multirow[t]{5}{*}{3.} & Cawat anuman leaves ethanol extract at dose $50 \mathrm{mg} / \mathrm{ml}$ & 1 & 12 & 13 \\
\hline & & 1 & 12 & 14 \\
\hline & & 1 & 13 & 15 \\
\hline & & 1 & 12 & 17 \\
\hline & & 1 & 12 & 18 \\
\hline \multirow[t]{5}{*}{4.} & $\mathrm{NaCl} 0.9 \%^{*}$ & 1 & $>24$ & $>24$ \\
\hline & & 1 & $>24$ & $>24$ \\
\hline & & 1 & $>24$ & $>24$ \\
\hline & & 1 & $>24$ & $>24$ \\
\hline & & 1 & $>24$ & $>24$ \\
\hline
\end{tabular}

\footnotetext{
* Observations up to 24 hours have not shown paralysis and death
} 
Table 2: The average of paralysis time and time of death of Ascaridia galli worms for 24 hours after immersion with mebendazole at dose $5 \mathrm{mg} / \mathrm{ml}$, cawat anuman leaves ethanol extract at dose $25 \mathrm{mg} / \mathrm{ml}$, and cawat anuman leaves ethanol extract at dose $50 \mathrm{mg} / \mathrm{ml}$.

\begin{tabular}{|c|c|c|c|}
\hline No & Group & $\begin{array}{l}\text { Time of Paralysis } \\
\text { (hours) }\end{array}$ & Time of Death (hours) \\
\hline 1. & Mebendazole at dose $5 \mathrm{mg} / \mathrm{ml}$ & $12.4 \pm 0.55^{\mathrm{a}}$ & $15.6 \pm 2.08^{\mathrm{a}}$ \\
\hline 2. & $\begin{array}{l}\text { Cawat anuman leaves ethanol extract at dose } 25 \\
\mathrm{mg} / \mathrm{ml}\end{array}$ & $13.4 \pm 0.55^{\mathrm{b}}$ & $18.0 \pm 1.59^{\mathrm{a}}$ \\
\hline 3. & $\begin{array}{l}\text { Cawat anuman leaves ethanol extract at dose } 50 \\
\mathrm{mg} / \mathrm{ml}\end{array}$ & $12.2 \pm 0.45^{\mathrm{a}}$ & $15.4 \pm 2.17^{\mathrm{a}}$ \\
\hline
\end{tabular}

* The difference in the superscript is significant $(\mathrm{p}<0.05)$

Bauhinia sp. or cawat anuman is one of the types of plants used by residents in Anik Hamlet as traditional anthelmintic medicine. This plant comes from the Fabaceae family. The Fabaceae family consists of several types including Bauhinia purpurea Linn., Bauhinia tomentosa Linn., and Bauhinia semibifida Linn. According to Wibisono \& Zikri $(2017)^{12}$ Bauhinia tomentosa leaves are used by the people of Samboja, Kutai Kartanegara, Indonesia as a medicine for wounds, fever and diarrhea The leaves of Bauhinia purpurea have hepatoprotective activity with an effective dose $500 \mathrm{mg} / \mathrm{kg} \mathrm{BW.}{ }^{13}$ The boiled water of Bauhinia semibifida root is used by the people of Ambawang Village as a medicine for body aches, ${ }^{14}$ and the people in Anik Hamlet use boiled water from the leaves of Bauhinia sp. or by the local community, it is referred to as cawat anuman as an anti-worm medicine (anthelmintic).

In connection with the use of plants as anthelmintics, there are various types of plants that have been shown to have anthelmintic properties, including Allium sativum or garlic, ${ }^{16}$ leaves of Orthosiphon aristatus or kumis kucing, ${ }^{7}$ leaves of Carica papaya or pepaya, ${ }^{17}$ and fruits of Morinda citrifolia or mengkudu. ${ }^{18}$ The anthelmintic power of preparation can be seen from the ability of the preparation to kill worms. Worms that are put into the test preparation are said to die if they no longer move if they are disturbed by a stirring rod and if they are transferred to distilled water at a temperature of $50^{\circ} \mathrm{C}$, but if the worms are still moving it indicates that the worm is experiencing paralysis or paralysis of muscle function. Furthermore, the time of paralysis is expressed as the time when the preparation starts to cause an effect. The activity of an extract as an anthelmintic is also seen from the time and number of worm deaths. ${ }^{11,19,20,21}$ In line with this statement, from the results of the observations made also it appears that there is paralysis in the worms which is characterized by no movement of the worms when disturbed by a stirring rod, it's just that when put into distilled water with a temperature of $50^{\circ} \mathrm{C}$ the worms keep moving. The death of worms is marked by a change in color to a paler color, the body becomes stiff, and the body becomes lysis (destroyed). Sutar et al. (2010) ${ }^{22}$ states that worms are said to be dead when they lose their motility and are followed by fading of their body color, even if they are put in hot water $\left(50^{\circ} \mathrm{C}\right)$ they also do not experience any movement at all. ${ }^{19}$

In line with the statement of Sirama et al. (2019) ${ }^{23}$ consuming nutritious plants can kill worms through the effects of secondary metabolite. In this research, from the results of qualitative phytochemical tests carried out on cawat anuman leaves, it is known that the ethanol extract leaves contain phenol and saponin. There are many different types of secondary metabolites including, flavonoids, ${ }^{24,25}$ phenols, ${ }^{25,26}$ saponins, ${ }^{25}$ tannins, ${ }^{25,27}$ terpenoids, ${ }^{25,28}$ steroids, ${ }^{25}$ and alkaloids. ${ }^{25}$ These compounds have medicinal benefits. ${ }^{26,27,29,30}$ Saponins, alkaloids, polyphenols, tannins, and flavonoids are reported to have anthelmintic activity against Ascaridia galli worms. ${ }^{31,32}$ The anthelmintic mechanism of each plant differs depending on the group of metabolite secondary it contains. ${ }^{11,33,34,35,36,37,38}$ Saponin compounds have a mechanism as an anthelmintic by inhibiting the acetylcholinesterase enzyme, so that the worms will experience muscle paralysis which results in the worms dying. ${ }^{33}$ According to Putra et al. (2014) $)^{34}$ alkaloid compounds will inhibit the work of the cholinesterase enzyme which causes muscle paralysis, resulting in the death of worms. When in direct contact with the body of the worm, the phenol compounds contained in the test preparation will cause denaturation of proteins in the tissue, causing death in worms. ${ }^{35,36}$ Tiwow et al. (2013) ${ }^{11}$; Hamzah et al. (2016) ${ }^{37}$; Sharma \& Prasad $(2014)^{38}$ state that the tannin compounds can damage the membrane in the worm so that the worms quickly experience paralysis, besides that the tannin compounds can inhibit the work of enzymes and interfere with the digestive metabolic process which causes the worms to lack nutrition and then dies. More than that, the tannin compounds are also ovicidal by binding to the proteins contained in the outer layer of the worm eggs, this bond will result in inhibition of cell division and result in larvae failing to form. Flavonoid compounds can denature the protein in worm tissue ${ }^{33}$ and can degenerate neurons in the worm's body, causing death, ${ }^{39}$ and can interfere with the formation of energy in the worm's body. ${ }^{22}$ Based on the results of previous researchers and the results of phytochemicals contained by the anuman cawat extract, it can be assumed that the ethanol extract of cawat anuman leaves has anthelmintic power. In connection with the saponin and phenol content in the ethanol extract of cawat anuman leaves, the anthelmintic mechanism is by inhibiting the acetylcholinesterase enzyme so that the worms will experience muscle paralysis which results in the worms dying and causing protein denaturation in the tissue, causing the death of the worms.

\section{CONCLUSION}

The anthelmintic activity of cawat anuman leaves ethanol extract at dose $50 \mathrm{mg} / \mathrm{ml}$ is equivalent to mebendazole at dose $5 \mathrm{mg} / \mathrm{ml}$.

\section{REFERENCES}

1. Perdana AS, Keman S. Hubungan higiene tangan dan kuku dengan kejadian enterobiasis pada siswa SDN Kenjeran No. 248 Kecamatan Bulak Surabaya. J Kesehat Lingkung. 2013;7(1):7-13.

2. Winita R, Mulyati, Astuty $\mathrm{H}$. Upaya pemberantasan kecacingan di sekolah dasar. Makara, Kesehatan. 2013;16(2):65-71

3. Rowardho D, Sayono, Ismail TS. Keberadaan telur cacing usus pada kuku dan tinja siswa sekolah alam dan non alam. J Kesehat Masy Indones. 2015;10(2):18-25.

4. World Health Organization. Soil-transmitted helminthiases: Eliminating soil-transmitted helminthiases as a public health problem in children, in Progress report 2001-2010 and strategic plan 20112020. France: WHO Press; 2012.

5. Departemen Kesehatan Republik Indonesia. Profil kesehatan Indonesia 2008. Jakarta: Departemen Kesehatan Republik Indonesia; 2009.

6. Tjay T, Rahardja K. Obat-obat penting khasiat, penggunaan dan efekefek sampingnya. Jakarta: PT. Elex Media Komputindo; 2007.

7. Ulya N, Endharti AT, Setyohadi R. Uji daya anthelmintik ekstrak etanol daun kumis kucing (Orthosiphon aristatus) sebagai anthelmintik terhadap Ascaris suum secara in vitro. Maj Kesehat FKUB. 2014;1(3):130-6. 
8. Febriani Y, Hidayat S, Seftiana S. Aktivitas anti cacing ekstrak etanol biji pinang (Areca catechu L.) terhadap Ascaridia galli. Indones J Pharm SciTechnol. 2014;3(2):1-7.

9. Yadav $P$, Singh R. A review on anthelmintic drugs and their future scope. Int J Pharm Pharm Sci. 2011;3(3):17-21.

10. Harborne JB. Metode fitokimia in Penuntun cara modern menganalisis tumbuhan. 2nd. Ed by Kosasi PN SI.Bandung: ITB Press; 1987.

11. Tiwow D, Bodhi W, Kojong NS. Uji efek antelmintik ekstrak etanol biji pinang (Areca catechu) terhadap cacing Ascaris lumbricoides dan Ascaridia galli secara in vitro. Pharmacon. 2013;2(2):76-81.

12. Wibisono Y, Azham Z. Inventarisasi jenis tumbuhan yang berkhasiat sebagai obat pada plot konservasi tumbuhan obat di KHDTK Samboja Kecamatan Samboja Kabupaten Kutai Kartanegara. J Agrifor. 2017;16(1):125-40.

13. Hanifa DD, Hendriani R. Review artikel: Tanaman herbal yang memiliki aktivitas hepatoprotektor. Farmaka. 2015;14(4):43-51.

14. Fadilah, Lovadi I, Linda R. Pemanfaatan tumbuhan dalam pengobatan tradisional masyarakat Suku Dayak Kanayatn di Desa Ambawang Kecamatan Kubu Kabupaten Kubu Raya. J Protobiont. 2015;4(3):4959.

15. Manalu S, Biran S. Infeksi cacing tambang. Cermin Dunia Kedokt. 2006;19.

16. Untari I. Bawang putih sebagai obat paling mujarab bagi kesehatan. Gaster. 2010;7(1):547-54.

17. Widiastuti R, Mardiyaningsih A, Putri YD. Uji aktivitas ekstrak etanol daun pepaya (Carica papaya) terhadap waktu kematian cacing Ascaridia galli Schrank secara in vitro, in The 2nd University Research Coloquium 2015, Universitas Muhammadiyah Semarang, Indonesia. 29 Agustus 2015.

18. Udayana P, Astuti K, Putra A. Uji aktivitas anti cacing dengan ekstrak etanol buah mengkudu (Morinda citrifolia Linn.) pada cacing gelang babi (Ascaris suum Goeze) secara in vitro. J Kesehat. 2016;1(2):95-8.

19. Rabiu H, Subhasish M. Investigation of in vitro anthelmintic activity of Azadirachta indica leaves. Int J Drug Dev Res. 2011;3(4):94-100.

20. Maulidya DA, Kahtan MI, Widiyantoro A. Daya antelmintik ekstrak etanol daun kesum (Polygonum minus) terhadap Ascaridia galli secara in vitro. J Cerebellum. 2017;3(1):731-40.

21. Robiyanto, Kusuma R, Untari EK. Potensi Antelmintik ekstrak etanol daun mangga arumanis (Mangifera indica L.) pada cacing Ascaridia galli dan Raillietina tetragona secara in vitro. Pharm Sci Res. 2018;5(2):81-9.

22. Sutar N, Garai R, Sharma US, Sharma UK, Jaiswal A. Anthelmintic activity of Platycladus orientalis leaves extract. Int J Parasitol Res. 2010;2(2):1-3

23. Sirama V, Kokwaro J, Owuor B, Yusuf A, Kodhiambo M. In-vitro anthelmintic activity of Vernonia amygdalina Del. (Asteraceae) roots using adult Haemonchus contortus worms. Int J Pharmacol Res. 2019;5(1):1-7.

24. Naik A, Dandekar S, Naik N. Effect of Indian honey on expression of p53 and cyclin B1 in HeLa cells. Indian J Biochem Biophys. 2020;57:178-84.
25. Bhat AH, Dar KB, Sofi MA, Dar SA, Zargar MA, Masood A, Ganie SA. Rheum spiciforme Royle-The medicinal herb with positive modulatory effect on controlled in vitro oxidative stress. Indian J Exp Biol. 2018;56(8):556-64.

26. Semerci $A B$, İnceçayir $D$, Konca $T$, Tunca $H$, Tunç $K$. Phenolic constituents, antioxidant and antimicrobial activities of methanolic extracts of some female cones of Gymnosperm plant. Indian J Biochem Biophys. 2020;57(3):298-303.

27. Shukla D, Gahlot K. Evaluation of antidiarrhoeal activity of the leaves and stem of Bauhinia vahlii. Pharmacogn J. 2020;12(6):1389-94.

28. Jasmine $R$, Kumar $A G$, Rajaram R. Probing the mechanism of the anti-diabetic potential of a terpenoid from Elephantopus scaber $\mathrm{L}$., an Indian ethnomedicinal plant in STZ diabetic rats-In vivo and in silico analysis. Indian J Biochem Biophys. 2018;55:384-8

29. Agrawal N D, Nirala SK, Bhadauria M, Srivastava S, Shukla S Protective potential of Moringa oleifera Lam. along with curcumin and piperine against beryllium-induced alterations in hepatorenal biochemistry and ultramorphology in rats. Indian J Biochem Biophys. 2019;56(1):70-80.

30. Sharma S, Mishra V, Srivastava N. Protective effect of Trigonella foenum-graecum and Cinnamomum zeylanicum against diabetes induced oxidative DNA damage in rats. Indian J Biochem Biophys. 2020;57(1):15-26.

31. Herawati $H$, Husin N. Berbagai jenis tumbuhan yang berkhasiat sebagai obat kecacingan. Media Litbang Kesehat. 2000;10(1):2-11.

32. Soeryoko H. Tanaman obat terpopuler penurun hipertensi. Yogyakarta: Andi Publishing; 2011.

33. Intannia D, Amelia R, Handayani L, Santoso HB. Pengaruh pemberian ekstrak etanol dan ekstrak $\mathrm{n}$-heksan daun ketepeng cina (Cassia alata .L) terhadap waktu kematian cacing pita ayam (Raillietina sp.) secara in vitro. J Pharmascience. 2015;2(2):24-30.

34. Putra B, Astuti K, Dwinata I. Uji in vitro ekstrak etanol buah nanas (Ananas comosus (L.) merr) terhadap daya mortalitas cacing gelang babi (Ascaris suum Goeze). J Farm Udayana. 2014;3(2):82-6.

35. Velmurugan C, Thomas S, Bhargava A, Shajahan S. Anthelmintic activity of leaves of different extracts of Gossypium herbaceum Linn. Int J Pharmacol Clin Res. 2018;1(2):38-44.

36. Calneck B. Disease of poultry, $10^{\text {th }}$ Edition . USA:The lowa State University Press; 1997.

37. Hamzah A, Hambal M, Balqis U, Darmawi, Maryam, Rasmaidar, Athaillah F, Muttaqien, Azhar, Ismail, Rastina \& Eliawardani. In vitro anthelmintic activity of Veitchia merrillii nuts against Ascaridia galli. Tradit Med J. 2016;21(2):55-62.

38. Sharma M, Prasad I SB. Evaluation of anthelmintic activity of leaves extracts of Guazuma tomentosa. Int J Pharmacol Phamaceutical Sci. 2014;1(1):1-5.

39. Lasut VN, Yamlean PV, Supriati HS. Uji efektifitas daya antelmintik infus daun ketepeng cina (Cassia alata L.) terhadap cacing gelang (Ascaris lumbricoides) secara in vitro. J IIm Kesehat. 2012;1(2):1-6. 


\section{GRAPHICAL ABSTRACT}

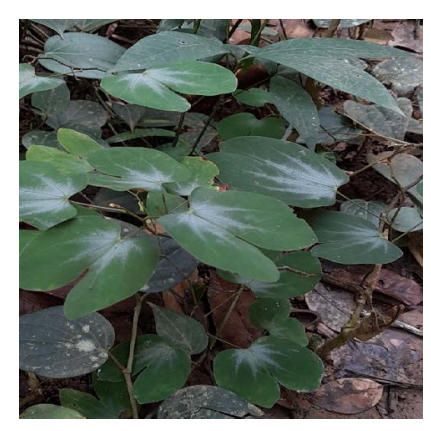

Cawat Anuman (Bauhinia sp.)

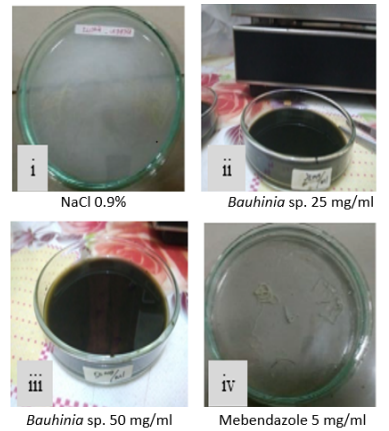

Anthelmintic Activity

\begin{tabular}{cccc}
\hline No & Group & $\begin{array}{c}\text { Time of Paralysis } \\
\text { (hours) }\end{array}$ & $\begin{array}{c}\text { Time of Death } \\
\text { (hours) }\end{array}$ \\
\hline 1. & Mebendazole at dose $5 \mathrm{mg} / \mathrm{ml}$ & $12.4 \pm 0.55^{\mathrm{a}}$ & $15.6 \pm 2.08^{\mathrm{a}}$ \\
& $\begin{array}{l}\text { Cawat anuman leaves ethanol } \\
\text { extract at dose } 25 \mathrm{mg} / \mathrm{ml}\end{array}$ & $13.4 \pm 0.55^{\mathrm{b}}$ & $18.0 \pm 1.59^{\mathrm{a}}$ \\
3. $\quad \begin{array}{l}\text { Cawat anuman leaves ethanol } \\
\text { extract at dose } 50 \mathrm{mg} / \mathrm{ml}\end{array}$ & $12.2 \pm 0.45^{\mathrm{a}}$ & $15.4 \pm 2.17^{\mathrm{a}}$
\end{tabular}

4. $\mathrm{NaCl} 0.9 \%$

Observation up to 24 hours have not shown paralysis and death

* The difference in the superscript is significant $(\mathrm{p}<0.05)$

\section{ABOUT AUTHORS}

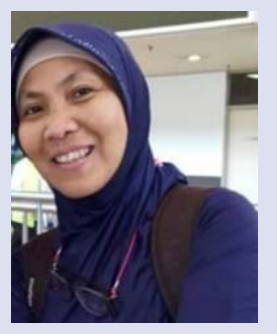

Ruqiah Ganda Putri Panjaitan, graduated from the Department of Biology, FMIPA Andalas University, Padang. She got her masters and doctorates from the Department of Biology FMIPA Bogor Agricultural University. Her field of interest is the study of medicinal plant activity. Now, she is working as a lecturer in Tanjungpura University.

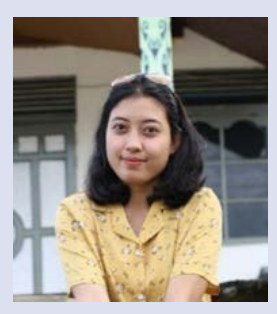

Ela Elisa, completed her bachelor's degree in biology education study program, FKIP, Tanjungpura University, Pontianak-Indonesia.

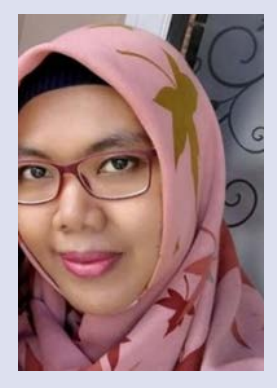

Eko Sri Wahyuni, her field of interest is the biology education. Now, she is working as a lecturer in Tanjungpura University.

Cite this article: Panjaitan RGP, Elisa E, Wahyuni ES. The Anthelmintic Activity of Cawat Anuman (Bauhinia Sp.) Leaves Against Ascaridia galli Worms. Pharmacog J. 2021;13(3): 626-30. 